\title{
PRIVATE PARTNERS AND THE PUBLIC GOOD
}

\section{Robin Wilson, Director of Democratic Dialogue, Northern Ireland." INTRODUCTION}

\section{The Problem}

The current Programme for Government of the devolved administration, like the first, sets out starkly the fiscal constraints confronting it:

"The resources available from the taxpayer are finite and in particular are stretched by the need to provide services for a higher proportion of young people and to tackle higher levels of social disadvantage than the UK average. We have a major need for significant investment, in particular in some of our infrastructure such as transportation, water and sewerage. However, the many other pressures on the Northern Ireland Block are such that the levels of required investment are unlikely to be solely achievable through public expenditure. Additional sources of investment will be secured including partnerships with the private sector as a means of tapping into expertise and new sources of finance; exploring other sources of revenue; and continuing to require developers to bear the cost of works needed to facilitate their development proposals". ${ }^{1}$

The programme promised that by September 2002 policy proposals on PPPs would be advanced and by October a review of rating policy would be complete. Currently, the regional rate provides the only "tax" the devolved administration can vary.

* This paper was published originally as the first in a series of briefing papers by the Institute of Governance, Public Policy and Social Research in Queen's University Belfast. It arose out of a round table event organised in February 2000 by the Institute of Governance under the Chatham House Rule which benefited from the valued contributions of the Northern Ireland finance minister, Seán Farren; the chief economist of the Institute for Public Policy Research, Peter Robinson; Nigel Annett, an executive director of Glas Cymru (the not-for-profit now running Welsh Water); and Eamon Kearns, head of the Public-Private Partnerships Unit of the Department of Finance in the Republic of Ireland. The paper also benefits from the contributions by round-table participants, none of whom of course bears any responsibility for its contents. These included some members of a Working Group on public-private partnerships (PPPs), convened by the Office of the First Minister and Deputy First Minister, which included representatives of employers, the trade unions and the voluntary sector as well as officials. The paper is an intervention in a debate about PPPs in Northern Ireland but it is hoped that its views may have wider application.

1 Northern Ireland Executive, Programme for Government: Making a Difference 2002-2005, (2001) Belfast: Office of the First Minister and Deputy First Minister, pp 68-69. 
The backdrop to these comments is a fairly bleak fiscal outlook. On the one hand, the administration is under strong pressure to "make a difference" in addressing what has come to be described as the "infrastructure deficit" in public services bequeathed by successive direct-rule administrations - for whom political crisis-management, rather than long-term policy commitments, was uppermost. On the other, it faces on the revenue side a "Barnett squeeze" in the growth of its public-expenditure allocation from Westminster.

In March 2001, the Executive Committee established a Working Group to carry out the review of PPPs promised in the first Programme for Government. ${ }^{2}$ Its terms of reference included "to look specifically at ways of attracting private sector investment to finance the provision of infrastructure, facilities and/or premises for the purposes of services to the public, where this provides value for money and is acceptable in relation to the Executive's other policy objectives and drawing on relevant UK and international practice". 3 The group concluded: "there is a need for substantial investment in Northern Ireland's public service infrastructure, for which there is currently inadequate funding from conventional sources . . . The gross investment deficit amounts to $£ 6.8$ billion over the next decade, with investment need significantly outstripping capital baseline funding. This highlights the potential for PPPs to address investment need, and thus assist in tackling the deficit, and also the need for alternative sources of funding in order to maintain, let alone improve, service provision." 4

The biggest single need identified, by department, is Regional Development, estimated at requiring a total of $£ 2.6$ billion more for investment over ten years, over and above current allocations projected forward. The major factors here are water and sewerage below ground, and transport above it. The other two departments, with estimated gross investment deficits of $£ 1.06$ billion and $£ 1.4$ billion respectively, are Education and Health, Social Services and Public Safety. Here schools, colleges and hospitals are the big investment costs. Between them, these three departments are estimated by the group to account for three quarters of the "gross deficit". ${ }^{5}$ In other words, were the challenges associated with them to be successfully tackled, the financial problem would in large measure be solved.

The deficit is slightly reduced when account is taken of the crossdepartmental Executive Programme Funds of the devolved administration. The group estimates this brings what it calls the "net investment deficit" down by nearly one billion to $£ 5.9$ billion over the decade. ${ }^{6}$ But this is still alarmingly higher than an earlier draft had calculated: $£ 4.1$ billion. The latter had been the basis for ministerial speeches declaring there was a $£ 4$ billion

2 Northern Ireland Executive, Programme for Government: Making a Difference 2001-2004, (2000) Belfast: Office of the First Minister and Deputy First Minister at p 69.

3 Office of the First Minister and Deputy First Minister. Review of Opportunities for Public Private Partnerships in Northern Ireland: Working Group Report, (2000) Belfast: OFMDFM at $\mathrm{p} 2$.

4 Supra pp 14-15.

5 Supra p 16.

6 Ibid. 
"infrastructure deficit" for the executive to fill, as Dr Farren repeated as late as March $22^{\text {nd }}$ in Derry:

"Unfortunately, we do not have the resources needed to rectify this problem. We will continue to utilise whatever funding is available from Europe and from other international sources, but the reality is that there will always be a gap between what we want to do and can afford to do. With a potential funding deficit already of around $£ 4$ billion we have to look beyond conventional procurement and towards Public-Private Partnerships and the Private Finance Initiative as one of the means of delivering the objectives of the Programme for Government."'

Dr Farren reported that 24 projects worth $£ 167$ million had been awarded under PFI in Northern Ireland, nine more worth $£ 170$ million were at various stages of procurement and 16 , potentially worth $£ 380$ million, were under active consideration.

The deficit is put down to the cumulative effect of capital expenditure constraints under the Tories, but continued under New Labour - by 19992000 net expenditure on assets had fallen to 3.6 per cent of the Departmental Expenditure Limit - as well as increased EU regulatory requirements with regard to water and waste, technological advances such as vis-à-vis medical equipment and the pressures of demography and social need. ${ }^{8}$

It is clear from the above that the thrust towards PPPs in Northern Ireland has been as a means of financing the infrastructure deficit through PFI projects. Yet the report makes plain that finance and funding need to be distinguished. Following the argument of the Institute for Public Policy Research commission on PPPs, ${ }^{9}$ (IPPR, 2001), the group recognises that, however a particular project is financed, unless charges are involved it is still funded from the public purse.

"A key source of confusion in the debate on Public Private Partnerships is the failure to distinguish between how public service investment is funded and how public service investment is financed. Public Private Partnerships do not in themselves give rise to new or additional sources of funding (unless they are associated with the introduction of user charging) and instead a stream of resource payments has to be set aside by the public sector in order to meet the financial commitments arising from the transaction. Unless a Public Private Partnership delivers net savings through greater efficiency, the ultimate cost of a project to the taxpayer will be higher than the cost of a traditional procurement where the Treasury borrows in the capital markets." 10

7 Executive Information Service, March $22^{\text {nd }} 2002$.

8 Working Group op cit $\mathrm{n} 3$ at $\mathrm{pp}$ 19-20.

9 Institute for Public Policy Research, Building Better Partnerships: The Final Report of the Commission on Public Private Partnerships, (2001) London: IPPR.

10 OFMDFM op cit $\mathrm{n} 3$ at $\mathrm{p} 33$. 
Unfortunately, this very clear statement is not followed consistently in the remainder of the report. For example, later it asserts:

"The financial modelling is predicated on three key assumptions:

Traditional procurement is the preferred way of meeting investment needs;

Capital budgets are used to meet investment needs through traditional procurement;

Public Private Partnerships are used to meet investment needs in excess of the capital budgets (i.e. PPP is used to fund the investment deficit)."11

Not only does this restate the "something-for-nothing" fallacy about PFI. On the other hand, it also questions the repeated - though not evidence-based assertion in the report that the private sector has "skills" which make it inherently more efficient than the public sector. If the latter were indeed so, far from there being a preference for "traditional procurement", there should be a preference (as under the Tories) for private-sector solutions, with no reference to public-sector comparators.

Worse still, this confusion is carried forward by ministers in their initial response to the Working Group report:

"As stated in our Programme for Government a central aim of the Executive is that through renewed infrastructure and innovative policies, we can secure the basis for a balanced, competitive, innovative and sustainable economy. It is clear that the level of resources routinely available to us would not be sufficient to achieve this outcome. In particular, dependence alone on routine public expenditure to fund infrastructure would make it much less likely that we could secure either the range or the quality of public services we need for Northern Ireland now and in the coming years.

Hence the Executive launched the Working Group on Public Private Partnerships last spring because we knew that, faced with a probable investment deficit in public services infrastructure of around $£ 6$ billion over the next 10 years, it was essential to explore vigorously all the options for bridging the gap. The use of Public Private Partnerships is one possible means of addressing the deficit ...

... We need to establish if PPPs can promote activity over and above what is possible from public spending and borrowing, and how that approach can be harnessed to serve the public interest here." 12

11 Supra at pp 145-6.

12 Northern Ireland Executive, Financing our future: initial response to report of working group on review of opportunities for public private partnerships in Northern Ireland, (2002) Belfast: Executive Information Service. 
Nor are ministers' assembly colleagues any more clearly informed. The report on PPPs by the Committee for Finance and Personnel declared: "The underlying assumption made is that HM Treasury is unlikely to meet all of the financial needs of Northern Ireland from increased public expenditure in the short to medium term." 13

This only confirms the view of Broadbent and Laughlin that "at the heart of PFI is an uncertainty about what its major public purpose is." 14 On the one hand, it is represented as a means to get round public-expenditure constraints and thus secure otherwise unaffordable investments; on the other it is described as a form of public procurement that can realise value-for-money savings and risk transfer in the public interest. They point out that two major changes have taken place under New Labour which have made the case for PFI significantly more restrictive.

The first is the adoption by the Chancellor, Mr Brown, of the "golden rule" and the "sustainable investment rule" for the public finances. ${ }^{15}$ This has legitimised sustainable borrowing for investment by the public sector and removed the "only show in town" argument for PFI. The freeing up of the borrowing capacity of the Northern Ireland administration via the Reinvestment and Reform Initiative, which could in turn be enhanced by an innovative, not-for-profit, special-purpose vehicle for water, have the same macro-economic effect on a regional scale.

This point is worth underscoring. There is no longer any case for resorting to PFI to evade public-expenditure restraints (though it was always shorttermist so to do). For Northern Ireland, unlike Scotland and Wales, there is now another show in town (apart from avoiding borrowing at all by raising revenues or reducing expenditures). There is now no excuse for there to be other than a procurement level playing-field.

This relates to the second change: the requirement, in line with National Audit Office guidance, that a public-sector comparator be designated to test the value-for-money potential of private project bids. Broadbent and Laughlin conclude: "It is now clear that if a PFI deal does not satisfy the value for money criteria in comparison with a PSC then it should not proceed."16 PPPs may offer savings over conventional procurement - if efficiency gains offset the transaction costs involved in the contracting process and the higher cost of borrowing which the private sector generally faces (because companies, unlike governments, may go bankrupt). But such savings cannot be generically assumed. And they will be at the margin, compared to the very large numbers the working group has generated. The argument for PPPs, if argument there be, must therefore be made otherwise: they will not fund the infrastructure deficit.

13 Committee for Finance and Personnel, Report on the Inquiry into the Use of Public Private Partnerships, report 7/00, (2001) Belfast: Stationery Office at p 7.

14 Control and legitimation in government accountability processes: the Private Finance Initiative in the $U K$, paper delivered to School of Management and Economics seminar, Queen's University Belfast, December $7^{\text {th }} 2001$.

15 Commission on Taxation and Citizenship, Paying for Progress: A New Politics of Tax for Public Spending, (2000) London: Fabian Society at pp 60-1.

16 Op cit $\mathrm{n} 14$ 
By the same token, whether PPPs are or are not pursued, the funding deficit still has to be addressed. There are only two ways of doing so: by increasing revenue or reducing expenditure. The revenue accruing to the devolved administration is overwhelmingly determined by UK-wide taxation and national-insurance arrangements, allied to the allocation of public monies to Northern Ireland, Scotland and Wales via the Barnett formula. The rates account for just 6 per cent of the regional budget. ${ }^{17}$ The formula was the eponymous creation of the cabinet secretary, Joel (now Lord) Barnett, in the last Labour government before the long period of Conservative rule. ${ }^{18}$ It was established in 1978 with the prospect of devolution in mind. The referendum "yes" in Scotland did not however meet the exacting requirements of the legislation of the time, while a majority in Wales voted "no". It is critical to understand that Barnett is a formula governing increments in expenditure, year on year, not levels of expenditure as such. Based on population ratios, expenditure in the devolved territories is increased in proportion to comparable programmes in England (or, in some cases in Northern Ireland, Great Britain).

The implication of this, in theory, is that ceteris paribus expenditure in Northern Ireland, Scotland and Wales, which all enjoy higher spending per head than England, should converge with the English level over time, as the percentage increase in English expenditure translates into "Barnett consequentials" for the devolved territories that comprise a lower proportion of their (higher) expenditure. This should be particularly so for Northern Ireland, as it is the most out of kilter - running at 42 per cent more per head than England. ${ }^{19}$ The fact, however, over two decades on from the onset of the formula, that Northern Ireland still experiences such a high differential over other UK regions/nations (Scotland comes next) suggests that the "Barnett squeeze" has not operated quite as expected. This is partly because of "formula bypass", where monies are allocated - such as the postagreement Chancellor's Initiative in Northern Ireland - outwith the formula. But stricter application of the formula - the change from the 1998 initiative, based on grants, to the 2002 Reinvestment and Reform Initiative, based on loans, is a signal - may reduce the scope for such bypass in future. Moreover, the 80s and 90 s were a period of slow public-expenditure growth. It is when, as now, rates of growth are more ambitious that the "squeeze" becomes tightest. ${ }^{20}$

Yet, as indicated above, PFI does nothing to loosen it. Indeed, on the contrary, if the expectation is of a progressively more constricted financial envelope, the dangers of adopting a "buy now, pay later" approach are all the

17 Department of Finance and Personnel, A Review of Public Procurement: Findings and Recommendations, (2002) Belfast: DFP at $\mathrm{p} 9$.

18 R. Barnett, and G. Hutchinson, "Public expenditure on the eve of devolution", in Robin Wilson (ed), Hard Choices: Policy Autonomy and Priority-setting in Public Expenditure, (1998) Belfast: Democratic Dialogue / Eastern Health and Social Services Board / Northern Ireland Economic Council at p 49-50.

19 HM Treasury, Public Expenditure Statistical Analysis (PESA) 2002-03, (2002) at p 95 (available at http://www.hm-treasury.gov.uk/Documents/Public_Spending and_Services/Public_Spending_Statistics/pss_pss_pesaindex.cfm)

20 David Heald, Beyond Barnett? Funding devolution, paper delivered at ESRC/IPPR devolution seminar, Scottish Parliament, April $18^{\text {th }} 2002$. 
more apparent. Treasury projections assumed big post-devolution increases in PFI commitments in the devolved territories, even as some central departments have been cutting back. ${ }^{21}$ In comments delivered in Edinburgh but equally applicable to Northern Ireland, Heald has pointed out: "The standard justification offered politically in Scotland for the adoption of the PFI route is one of capital starvation and the non-availability of public funds ('only show in town'); this sits uncomfortably with concerns that the Barnett formula will in future bring convergence." 22 Moreover, there is little point in Northern Ireland ministers protesting that Barnett is "unfair", with a view to securing an even larger differential over and above the UK average. As Heald bemoans, "There is presently a remarkable amount of confusion about even basic facts, stemming in part from an apparent failure to understand the difference between relative and absolute changes." 23 It is precisely because Northern Ireland receives such generous funding, compared with the UK average, that absolute changes in levels translate into what can be presented as miserly relative gains. Any needs assessment, the only alternative to Barnett - based on setting levels rather than increments - would be very unlikely to find that greater social need in Northern Ireland, however severe, justified a 42 per cent spending bonus over England. Indeed, if they encouraged the Treasury to go down that road, Northern Ireland ministers might find themselves struggling to defend what they had, rather than making further advances.

A Treasury review of disparities in expenditure between English regions could potentially spill over into the devolved territories in any case. Indeed, the devolved countries and regions team at the Treasury has calculated that, even taking account of extra security costs, Northern Ireland would lose $£ 364$ per head per year - a 5.7 per cent reduction - if spending were reallocated according to need. ${ }^{24}$ Given pressures from similarly poor but less-well-funded regions like the north-east of England, as Smyth and Delargy warn, "It is far from clear that if the cake were shared out in a different way, we would emerge as winners." ${ }^{25}$ Nor is the "unfairness" case made any stronger by the record of the Northern Ireland departments since devolution. The fragmentation of government from six to 11 departments (including the OFMDFM) has compounded the spending-control mindset inherited from a more stringent régime by making it more difficult to disburse allocations. In 2000-01, the departments underspent by nearly 4 per cent. $^{26}$

The problem, then, is not the one we started with, and not the one that is normally presented in the public domain. Northern Ireland's problem is not that it is "underfunded" by Westminster in terms of public expenditure though, like the rest of the UK, it is under-taxed compared with the EU average, and therefore endures sub-European public services. And nor, in this context, does the private sector offer a vehicle to magic gold out of base

21 Institute of Public Policy Research, op cit $\mathrm{n} 9$ at $\mathrm{p} 75$.

22 Op cit $\mathrm{n} 19$.

23 Ibid.

${ }^{24}$ Guardian, July $1^{\text {st }} 2002$.

25 Austin Smyth, and Jamie Delargy, Bonds: A Capital Idea, (2001) unpublished paper.

26 Heald op cit. 
currency. Over the long run, funding the "infrastructure deficit" can only be done by diverting expenditure from elsewhere or enhancing revenue. PPPs, if they have a role, must be embraced for other reasons.

\section{Wider Considerations}

All over the world, governance is changing. Launching the Institute of Governance and Public Management at Warwick University in September 2001, its director, John Benington, presented three competing and to an extent successive, paradigms - traditional public administration, the "new public management" and emergent "citizen-centred governance" reproduced, with acknowledgment, in Figure One below. In the first, the state both proposes and disposes; in the second, the consumer (theoretically) proposes and the market disposes; in the third, the citizen (as far as is practicable) proposes and networks / partnerships dispose.

Figure One: The Warwick model of competing paradigms of governance ${ }^{27}$

\begin{tabular}{|l|l|l|l|}
\hline & $\begin{array}{l}\text { Traditional public } \\
\text { administration }\end{array}$ & $\begin{array}{l}\text { New public } \\
\text { management }\end{array}$ & $\begin{array}{l}\text { Citizen-centred } \\
\text { governance }\end{array}$ \\
\hline Context & Stable & Competitive & $\begin{array}{l}\text { Continuously } \\
\text { changing }\end{array}$ \\
\hline Population & Homogeneous & Atomised & Diverse \\
\hline Needs/problems & $\begin{array}{l}\text { Straightforward, } \\
\text { defined by } \\
\text { professionals }\end{array}$ & $\begin{array}{l}\text { Wants, } \\
\text { expressed } \\
\text { through the } \\
\text { market }\end{array}$ & $\begin{array}{l}\text { Complex, } \\
\text { volatile and } \\
\text { prone to risk }\end{array}$ \\
\hline Strategy & $\begin{array}{l}\text { State- and } \\
\text { producer-centred }\end{array}$ & $\begin{array}{l}\text { Market- and } \\
\text { consumer- } \\
\text { centred }\end{array}$ & $\begin{array}{l}\text { Shaped by civil } \\
\text { society }\end{array}$ \\
\hline $\begin{array}{l}\text { Governance } \\
\text { through ... }\end{array}$ & Hierarchies & Markets & $\begin{array}{l}\text { Networks and } \\
\text { partnerships }\end{array}$ \\
\hline Actors & Public servants & $\begin{array}{l}\text { Purchasers and } \\
\text { providers, } \\
\text { clients and } \\
\text { contractors }\end{array}$ & Civic leaders \\
\hline
\end{tabular}

This table is important because it is widely assumed that in fact there are only two models of governance: the first, frequently presented as obsolete, and the second, assumed to represent the only alternative. Much of the drift in Britain in the 80s and 90s from delivery of projects and services via the public sector towards reliance on the private sector was premised upon such

27 Copyright: John Benington and Jean Hartley, University of Warwick, Coventry CV4 7AL, UK. 
presuppositions. This included the idea that there should be a preference for private finance, associated with the private-finance initiative.

Awareness of the third paradigm, and in particular of the role of nongovernmental organisations and civil society in governance, allows of a recognition that the "public sphere" may be broader than the state and, indeed, that the latter may not represent its best embodiment. Within this model, it is at least theoretically possible that the state could contract, withdrawing from service delivery towards more strategic core functions, while the public sphere expanded, as operational control over services was devolved to a diverse range of organisations, subject to democratic regulation. An obvious example in many continental-European countries is social-insurance schemes, frequently managed by the "social partners" rather than by government itself. A Northern Ireland example would be the operation of refuges for victims of domestic violence by Women's Aid, rather than by the Department of Health, Social Services and Public Safety (which nevertheless finances them). The arrangement is allied to a regional forum on domestic violence, which brings all the relevant statutory and voluntary agencies together.

This point is particularly important in that in the UK, and especially in Northern Ireland, discussion of PPPs has taken place in a context where it has been (wrongly) assumed that they necessarily arise from publicexpenditure restraint. The IPPR commission on PPPs, by contrast, called for further exploration of the potential of PPPs and greater commitment to public expenditure. And it pointed out that "many of the societies that see a diverse set of public service providers as a natural state of affairs have levels of public investment and social provision that ... the UK can only envy". ${ }^{28}$

Understanding this third paradigm makes clearer that PFI, which has been the almost-exclusive focus of the PPP debate in Northern Ireland, represents only one instance of the kinds of partnership into which the state can enter. There is a danger that it becomes a "cuckoo in the nest", crowding out other, often more interesting, partnerships, such as in policy delivery and service provision. A broader approach can conceive of the potential benefits of notfor-profits, for example.

Glas Cymru is a not-for-profit which took over the privatised Welsh Water organisation. It is a potential model for Northern Ireland which has interested the assembly's regional-development committee. It is accountable to 50 independently-appointed "members", who carry out the corporategovernance role of shareholders without taking any dividend, and has the support of the Welsh National Assembly. This means that it operates in the public rather than private-shareholder interest and is able to borrow more cheaply than if it were a private concern, and has done so through a bond issue. It has thus been able to cut bills as well as enhance reinvestment. (Again, of course, this is only cheaper, not free, capital.) Being not-forprofit, however, does not mean Glas Cymru avoids financial disciplines: it outsources much of its work competitively on the basis of target prices based on market research and performance-linked management fees. But it retains bath-to-bay responsibility for the whole system - thereby avoiding the

28 IPPR op cit $\mathrm{n} 9$ at $\mathrm{p} 253$. 
moral-hazard problems experienced on the railways in Britain, where the bewildering array of partners ensures everyone tries to displace responsibility on to somebody else when things go wrong.

The Working Group does consider Glas Cymru - though it underestimates the capacity of not-for-profits to be financially diligent, ${ }^{29}$ and so is more negative about them than the voluntary sector would like. ${ }^{30}$ But the skewing of the group's work, arising from its origins in the "infrastructure deficit", tends to narrow the focus nevertheless. The report of the Working Group recognises that one form of PPPs comprises arrangements "where the public and private sectors work together to bring about more general policy outcomes" but it says that the "nature and scale of the investment challenge" dictate a focus for the most part on the purchases of services from the private sector or the introduction of an element of private-sector ownership into state enterprises. ${ }^{31}$

This is unfortunate, once the something-for-nothing fallacy is understood on the one hand and the innovative potential of the third governance paradigm is appreciated on the other. For it is precisely via co-operation between a limited, liberal state and a wide range of NGOs (including the conventional private sector) that policy can often be best delivered in complex economic and social environments. Yet just one paragraph of the report is devoted to this potentially huge area. ${ }^{32}$ Looking at devolved governance in particular, apart from Northern Ireland's "infrastructure deficit", a further factor encouraging all the UK devolved administrations to go down the PFI route has been Treasury rules preventing the latter from borrowing in their own right. In that sense, while PFI does not offer something for nothing, it has appeared to offer something quicker, by getting projects "off balance sheet". The Working Group rightly recognised that this is a poor argument for PFI projects, trumping as it will value-for-money considerations, and the group recommended a relaxation of Treasury borrowing constraints. ${ }^{33}$

The significance of the Reinvestment and Reform Initiative launched in May $^{34}$ is that it provides a borrowing capacity. An initial $£ 125$ million facility has been made available and from 2004 the executive will be empowered to borrow without, apparently, any limit. According to $\mathrm{Mr}$ Brown, "in the spirit of devolution, it will be for the Executive to decide how far and how fast to make use of this new facility". ${ }^{35}$ As long as borrowing is to finance investment rather than recurrent expenditure, as long as the budget is such as to be able to meet the claims arising and as long as the opportunity costs are assessed, it can be justified. But, again, this is not

29 Op cit $\mathrm{n} 3$ at $\mathrm{p} 60$.

30 Northern Ireland Council for Voluntary Action, NICVA response to the draft working group report on the use of PPP/PFI in public services, (2002) Belfast: NICVA. Pp 3-4.

31 Working Group op cit at p 50.

32 Op cit at p 61.

3 Op cit at p 44.

34 See Irish Times, May $3^{\text {rd }} 2002$.

35 See speech by the Chancellor of the Exchequer, Gordon Brown MP, at the Odyssey Centre, Belfast - Reinvestment and Reform Package, (2002) (available at http://www.hm-treasury.gov.uk/Newsroom_and_Speeches/speeches/Chancellor Exchequer/speech_cx_020502.cfm). 
something for nothing. Indeed, borrowing can only be justified if it is sustainable. This can only be so if it generates, or is associated with the generation of, revenue which allows the repayment of the principal plus the compound interest accumulated. This is why, far from sidelining the issue, the Reinvestment and Reform Initiative stimulated debate as to how the region could contribute more on the revenue side.

If, then, the Northern Ireland administration, through the new Strategic Investment Body to be established under the initiative, can borrow in its own right, and if it can generally do so more cheaply than the public sector, why bother with exploring private partnerships at all? First, as indicated earlier and discussed further below, there are important non-financial grounds for exploring PPPs. But, secondly, PPPs may be more cost-effective.

The very opening up of public services to contest creates a competitive environment which incentivises the search for efficiency (which we can define as quality of service offset by cost). If the lowest-priced bid will always triumph (as under the old "compulsory competitive tendering" regime) and employee terms are not protected, this can lead to a "race to the bottom" at the expense of service quality and workforce conditions. But a focus on "best value" and safeguards for employees (see below) should ensure that the incentives direct managers to genuine efficiency improvements - by service innovation or cost reduction or both. Even if the public-sector comparator triumphs in such an environment, the contest will have demonstrated its superior efficiency or incentivised it to achieve such superiority.

The report in the Republic of Ireland of the Public-Private Advisory Group on PPPs argued that "all parties to a PPP arrangement should have regard to appropriate industry norms in terms of pay and conditions and of [sic] prevailing national and/or industry-wide agreements including health and safety regulations." 36 "Regard" is not a guarantee that existing terms and conditions will provide a floor, below which new employees will not be recruited, but the reference to wider norms and agreements provides a context in which such a floor can be constructed. The Working Group Report basically throws this issue, which continues to concern the trade unions, ${ }^{37}$ and indeed the voluntary sector, ${ }^{38}$ up to the executive. In terms of the correct structure of incentives, never mind Northern Ireland's muchvaunted "equality agenda", a level floor for all should be the objective.

Over and above the impact of contestability, if a PPP assumes control of a project there is a continuing financial incentive towards efficiency. This arises from the "stake" which the private partner has in the success of the project: a cost overrun, for instance, will reduce its profit stream accordingly, as long as there has been a genuine transfer of risk through a properly drawn contract. As long as the workforce terms-and-conditions floor is secure, this will have an effect nicely described by Audit Scotland in terns of how it "focuses the mind" (for the commissioning body as well as the contractor) on

36 Public-Private Advisory Group on PPPs (2001), Framework for Public Private Partnerships, Dublin: Department of Finance, available at http://www.ppp.gov.ie

37 See Working Group Report op cit at pp 172 and 203.

38 See NICVA response op cit $\mathrm{n} 30$ at $\mathrm{p} 4$. 
how the specified outputs will be delivered to the required standards of performance. Review arrangements may be critical in this regard. Otherwise, departments may find themselves having to top-slice budgets to meet contractual commitments which the benefit of hindsight shows to have been unwise. For example, in the early $90 \mathrm{~s}$ an albeit privatised Northern Ireland Electricity became locked into power-purchase contracts with private generating companies, stretching as far ahead as 2024. Despite the best efforts of the regulator to reduce prices, this has forced consumers domestic and industrial - to pay dearly for energy supplies in the region. ${ }^{39}$ The Northern Ireland Audit Office has expressed dissatisfaction with the arrangements on more than one occasion. ${ }^{40}$ How such conflicting pressures will work out in any particular instance can not be predicted. Hence, there is a strong argument for a case-by-case approach to PPPs, assessing how value for money is distributed among competing bids, rather than adopting an ideological assumption in favour of public- or private-sector solutions.

It is also important to avoid what has become frequent practice in Britain with PFI, which is the selection of a "preferred bidder". This approach is an attempt to assuage private-sector concerns about the expense of pursuing bids to a conclusion when they may well end in failure. The European Commission recommended in a draft directive in 2000, challenged by the UK government, that preferred bidders should be outlawed in the name of competition. Shortlisting is fine but the danger of allowing a single preferred bidder to emerge is that the latter can then engage in "rent-seeking" behaviour, securing concessions in the final negotiation of the contract from the public procurer - perhaps at the expense of service quality or workforce conditions - to maximise their return. ${ }^{41}$ The head of health policy at UCL and a long-time PFI critic, Allyson Pollock, has claimed that the first 14 PFI hospitals in Britain saw bed reductions averaging 30 per cent and cuts of 20 per cent in clinical-staff budgets. ${ }^{42}$ It is worth underscoring in this regard the dubiousness of talismanic claims of inherent private-sector capacities as against the real economic force of competition - including in the winning of contracts and then the realisation of a surplus from the associated investment (considering its opportunity costs). If the private sector is held to possess, say, skill in developing and managing large projects that the public sector lacks, then there are two obvious alternatives to PFI. The public sector could simply poach the specialist staff from the private sector or the latter could be contracted to run projects but not finance them - for example, design-buildoperate (DBO) arrangements as against design-build-finance-operate (DBFO).

It is also important to recognise that there may be sectoral specificities. The IPPR report ${ }^{43}$ noted that in the UK there was evidence of value-for-money savings through PFI projects in roads and prisons but that this was not the case for schools and hospitals. Part of the reason for this is that privatelyfinanced schools and hospitals are nevertheless staffed by publicly-employed teachers and medical staff. There is thus a fragmentation of management

39 See further Smyth and Delargy op cit.

40 See further for example Irish Times, 15 January 2002.

41 See further Guardian, 22 January 2002.

42 See further Guardian, 11 December 2001.

43 IPPR op cit at $\mathrm{n} 9$. 
arrangements and a disruption of relationships between, for instance, nursing and ancillary staff, which few would advocate solving by moving the relevant professional teams into the private sector (though the class assumptions behind who is legitimately transferred from the public sector and who is not are interesting in this regard).

The international evidence marshalled by the Working Group similarly shows that while PPPs in "physical" infrastructure - roads, transport, water are widespread, this is not the case for education and health. ${ }^{44}$ Notably, France, Germany and the Netherlands - as attractive as they come when it comes to public services - do not pursue PPPs in these arenas (though socialinsurance schemes in health might be so described by another definition).

This is important, given the earlier point about where the "infrastructure deficit" in Northern Ireland lies. Fascinatingly, moreover, while both education and health are ministries in Sinn Féin hands, the former minister, Martin McGuinness, quickly supported PFI arrangements, while the latter, Bairbre de Brún, has hitherto been reluctant to do so. Mr McGuinness, though representing a nominally socialist - indeed "revolutionary" - party in government, has taken over projects commenced not under the centrist New Labour but the right-wing Conservative direct-rule administration. In 1996, three schools and two further-education colleges in Northern Ireland were selected for the "Education Pathfinder" PFI project. Speaking at the site of one of the schools, St Genevieve's in west Belfast, the education minister rehearsed the "something-for-nothing" fallacy:

"Since taking up my post as Education Minister, I have been concerned about the legacy of under-funding which has left serious deficiencies in accommodation across the schools estate. I am paying particular attention to this and will continue to seek additional resources to improve the situation. PFI is an innovative procurement method which can complement conventional public sector capital investment and thereby enabling [sic] us to secure much higher levels of capital investment overall." 45

The thrust of the evidence is that in precisely these two big-spending areas education and health - one should not be pushed down the PFI route by the "something-for-nothing" fallacy or "only show in town" pressures to get projects "off balance sheet". The biggest single item in the third area regional development - is water, where an approach akin to that of Glas Cymru appears to be merited in Northern Ireland. In transport, meanwhile, the emphasis in the regional transport strategy on road-building has been rightly criticised by environmentalists, ${ }^{46}$ but there may be a residual role for PFI here. Moreover, it is worth underscoring, once the distinction between finance and funding is grasped, the limited nature of the potential PFI savings. The public policy editor of the Financial Times, Nicholas Timmins, has written: "Many of the models show only a marginal cost-saving of a few

44 Working Group op cit at $\mathrm{p} 73$.

45 Executive Information Service, September $14^{\text {th }} 2000$.

46 For example, R. Wilson, "Public policies", in Northern Ireland Devolution Monitoring Report no 10 (February 2002), available at http://www.ucl.ac.uk/constitution-unit/ . 
million pounds on PFI projects that have lifetime costs of tens or hundreds of millions of pounds." ${ }^{47}$ Interviewed in the same report, the Deputy Controller and Auditor-General at the National Audit Office warned that some comparisons against a PSC favouring a private bidder involved "pseudoscientific mumbo-jumbo" and were "utter rubbish". The report by Audit Scotland on PFI schools there, while confirming the real incentive effects of contestability and risk transfer, also indicated that VFM savings were marginal and, given the subjectivity of many assumptions, uncertain. Meanwhile, a "building futures" group, set up by the government-funded commission for architecture and the built environment and the Royal Institute of British Architects, has warned that 30-year contracts for PFI hospitals could lock the taxpayer into paying for what the group's chair called "institutional hospital buildings that mimic those of the Victorian era and will have little to do with the healthcare needs of our children's generation", when new technology and telecommunications would allow more people to be treated at home or in community settings. ${ }^{48}$

All in all, then, it may be that PFI will only play a limited part in Northern Ireland. Yet, if that were to militate in favour of a broader approach to PPPs and against the "cuckoo in the nest" danger - as well as that of mortgaging the future - it might better allow the full potential of PPPs properly to be realised. Were the devolved administration to pursue a VFM approach to the pursuit of PPPs, and recognise their diversity, there would be no need to pursue the "deal flow" of which the Working Group talks in commercial language which it would be quite inappropriate for the guardian of the public interest to adopt. ${ }^{49}$ This is, first, because VFM considerations must be caseby-case and such an approach would be prejudiced by an overall commitment to add more "deals" to the "flow". This is particularly so, given that the Working Group claims that "accelerated delivery" of projects is itself a VFM objective. ${ }^{50}$ Mortgaging the future could, in these terms, perversely translate into value for money! Secondly, once it is clear that PFI is only one of the types of partnership arrangement that may be pursued, it is clear that the commonality between "deals" is that much less. It is critical to distil experience at the heart of government on PPPs - a unit in the finance department, as in the Republic of Ireland, is suggested by the Working Group ${ }^{51}$ - but talk of a PPP "process" is not evidence-based and would be likely to engender unnecessary opposition. And to suggest that there is a need for a "collective political commitment" 52 to PPPs, in the abstract is, in that sense, meaningless.

In addition, it is worth stressing the "value" in the value-for-money argument. Oscar Wilde famously complained about those who understood the price of everything and the value of nothing. It is theoretically possible, for example, that the "best value" choice in a particular instance might be the most expensive, were the quality of service offered to be so high as to be felt more than to offset the cost incurred. In our daily lives, we often choose (if

47 Financial Times June $5^{\text {th }} 2002$.

48 Guardian, June $8^{\text {th }} 2002$.

49 Working Group op cit at $\mathrm{p} 101$.

50 Op cit at p 91.

51 Op cit at p 183.

52 Working Group op cit at p 117. 
we enjoy the choice) not to buy the least expensive of a range of goods on offer, recognising that good value rarely comes cheaply. Many of us, indeed, do not search out the lowest prices on the supermarket shelves, out of foodsafety, environmental, fair-trade or simply quality considerations. A small voluntary-sector organisation, for example, might not be able to achieve the economies of scale of corporations or the public sector, yet might be able to offer a combination of specialist expertise, flexibility, commitment and user engagement which were thought to be of overriding importance for delivery of a particular service. It is thus helpful that, again following IPPR, ${ }^{53}$ the Working Group recognises that partners can be drawn from the voluntary sector. ${ }^{54}$ In the light of the commitment in the Programme for Government to "building stronger partnerships with the voluntary and community sector", 55 as well as business and the trade unions, the Voluntary and Community Unit ${ }^{56}$ of the Department for Social Development has recently called for research proposals to address, inter alia, "the role and contribution of the voluntary and community sector in delivery of government services and identification of options for expanding the service delivery role of the voluntary and community sector". Not only that, but "social" (as against conventional "private" or "public") providers may engender beneficial "externalities" which will not appear in the accounting of that organisation. Pursuing neighbourhood regeneration, for example, in conjunction with a local social-economy organisation would not only deliver a service (local regeneration) but have spin-off benefits (local employment maintenance). The fact that the latter would not accrue to the project in hand would not mean it was of no value from the wider public interest.

It is because of this that Stutt et al have recommended that government in Northern Ireland adopt a preference for social-economy providers. ${ }^{57}$ Clearly, such a preference would have to be based on there being demonstrable positive externalities in the particular case and should not be allowed to trump all consideration of efficiency. But were such an approach not to be adopted, in favour of a narrowly economistic alternative, these important externalities might be unwittingly foregone.

Because the public sector looms so large in Northern Ireland, public procurement is a major lever in the hands of the devolved administration: it is estimated to account for over $£ 1.2$ billion per year. ${ }^{58}$ The review of public procurement recognises that "wider economic, social and environmental strategies and initiatives of the devolved administration in Northern Ireland should be more closely integrated into procurement policy". ${ }^{59}$ It does not go

53 IPPR op cit $\mathrm{n} 9$.

54 Working Group op cit at $\mathrm{p} 49$.

55 Northern Ireland Executive, Programme for Government (2001) op cit $\mathrm{n} 1$ at $\mathrm{p} 70$.

56 Voluntary and Community Unit, Voluntary and community sector research in Northern Ireland: guidance for submission of proposals, (2002) Belfast: Department for Social Development.

57 See C. Stutt, B. Murtagh and M. Campbell, The Social Economy in Northern Ireland: A Policy Review, (2001) available at http://www.colinstutt.com/social_ economy.htm.

58 Department of Finance and Personnel (DFP), A Review of Public Procurement: Findings and Recommendations, (2002) Belfast: DFP at $\mathrm{p} 4$.

59 DFP Review op cit at $\mathrm{p} 10$. 
so far as to recommend (or even discuss) the social-economy preference commended to government by Stutt et al but it does propose a pilot scheme where some 20 procurement projects would be linked to bidders' proposals to recruit from the unemployed. Moreover it does say that the Procurement Board envisaged should consider how social considerations could be further integrated. 60

From a public-interest perspective - which should drive all policy, whoever delivers it - a key issue of accountability arises when activities previously carried out in the public sector are devolved to partnerships or entirely to non-governmental organisations (including enterprises). Of course, the public sector can be unaccountable itself where transparency is lacking - and the devolved administration has got off to a bad start in this regard, accepting the conservative freedom-of-information regime devised by the former home secretary, Jack Straw, rather than the more liberal arrangements adopted in the republic or those envisaged in Scotland. But the risk of governance via the market is that claims of "commercial confidentiality" can be used to deny the public access to information that would be embarrassing to the company concerned or that might assist its competitors.

A broader, third-paradigm, focus on governance through networks and partnerships is, however, potentially exciting in accountability terms. Accountability can become an iterative dialogue between the partner(s) and government (at whatever level), to mutual benefit in terms of performance and innovation. Partnership arrangements may also facilitate direct accountability to the citizen via novel forms of user participation. Accountability may become more complex than in the first paradigm (via officials to elected representatives) but it may be the richer for that. Robust reporting requirements and periodic review arrangements can themselves incentivise the pursuit of efficiency, in addition to - or even as a substitute for - the commitment of a financial "stake". Thus, Glas Cymru's requirement to report to its "stakeholders" acts as a proxy for the latter, while avoiding its downside skewing effect on the operation of the company. Review arrangements can also prevent an inadvertent "democratic override", where a long-term and inflexible contract prepared in one policy context provides a source of inertia against the implementation of a more up-to-date one.

Moreover, while an organisation outside government may escape accountability, in well-constructed arrangements it is more specifically accountable: its budget is separate, for example, and so cost overruns will not be submerged in a larger departmental account. This would be likely to be critical if there were to be a move towards charging for water in Northern Ireland. The evidence of the Commission on Taxation and Citizenship ${ }^{61}$ is that citizens would be more willing to pay a discrete amount to a discrete body - particularly one with no private shareholders - than an undifferentiated rate increase to an anonymous bureaucracy. Given water is currently operated by the state, rather than privatised, in Northern Ireland, a way towards the Welsh model would be to set up a special-purpose vehicle

${ }^{60}$ Op cit at pp 50-2 and $\mathrm{p} 53$.

61 Commission on Taxation and Citizenship, Paying for Progress: A New Politics of Tax for Public Spending, (2000) London: Fabian Society. 
in which the existing assets would be invested and which could issue bonds, with the assembly as backstop. Plans and targets could be set by the assembly, to which the SPV would report, and periodically reviewed against performance.

Returning to the broad picture, reflecting on developments since the IPPR commission report, one of its authors, Peter Robinson, has recommended three actions by government - equally applicable at devolved level - which would reassure genuine doubters about PPPs. ${ }^{62}$ According to Robinson, a first step should be to lay to rest the bogus argument that PPPs somehow produce "extra" investment that the country could otherwise not afford. It has not in the past, it does not now, and it will not in the future. PFI may have its merits, but loosening the resource constraints that the country faces is not one of them. Clearing up this point would help ensure that private finance is only ever used for projects when it is genuinely thought that it will outperform a publicly financed alternative. Secondly, Robinson recommends an independent review of the process of evaluating value for money and, consequently, of the performance of PFI projects as compared with the alternatives. And, thirdly, he suggests inviting the trade unions and employers themselves to come up with a solution to the fear of a "two-tier workforce",

If the executive were to adopt these three stances, it would go a long way towards clearing the air - including of much of the confusion, uncertainty and fear surrounding the subject.

\section{The solution}

Let us return to the problem as we had redefined it: the gap between funding (as against financing) and public expenditure in Northern Ireland. We have stressed throughout that PPPs do not solve that problem. But, if conceived on a broad canvas - notably their underestimated potential in policy development and delivery - PPPs may have a major role to play in new governance arrangements, which we have defined as favouring a liberal state but a large "public sphere". They therefore may not answer the question of how we fund public services to a high standard, but they may be a big part of the answer to the question as to how we deliver such services and thereby, in a devolved context, "make a difference". Indeed, far from being a means to privatise government in line with a last-century governance model, PPPs offer Northern Ireland, where scope for institutional innovation is still large, avenues - plural, not singular - for moving towards a society characterised by higher public expenditure and greater reliance on non-governmental partners.

The remainder of this paper explores the various aspects of a solution. First, it looks at how revenue can be enhanced, including in the context of the rates review. Secondly, it addresses the specific challenge of renewing the water system. Thirdly, it considers expenditure, including issues of efficiency. Fourthly, it tackles the accountability concerns surrounding PPPs. And, finally, it indicates the positive role that ministers can and should play in carrying forward this debate.

62 P. Robinson, PPPs: the Evolving British Debate, unpublished paper (2001). 


\section{Revenue}

Take funding first. All public expenditure must be funded ultimately by taxation or charges. Given the scale of the subvention looms large in the former, the capacity of the administration to demonstrate that it is getting its own financial house in order is critical to ensuring the best envelope of provision (and it would be counter-productive to advocate the reopening of Barnett unless and until the chancellor does so).

Tax-varying powers are essential, for two reasons. The first is to help fund services and take the weight off the regressive regional rate. The second is politico-moral: it is unhealthy for any polity to have power to disburse expenditure out of all proportion to its power to collect revenue. Recommending that the power to vary income tax be extended from Scotland to all the devolved administrations (and that the revenue-raising powers of local authorities be freed up), the Commission on Taxation and Citizenship said of the current situation: "It allows politicians and governments at the sub-national level to blame their failings on the lack of money they have been given by central government. In turn it can lead devolved and local governments to become more like pressure groups seeking greater funds from the centre than bodies taking responsibility for their own decisions." ${ }^{63}$

The rates review simply ignores the issue of tax-varying powers, since they would require amendment of the Northern Ireland Act 1998 which implemented the Belfast Agreement. But on any objective reading of the agreement, a conference involving the parties, to review its operation, should have taken place by May 2002. The review could have addressed - and still should address - this issue, a lacuna which simply reflects the absence of political will. Indeed, even in the absence of the review, the assembly can legislate in "reserved" areas - such as taxation similar to that in Great Britain - with the agreement of the Northern Ireland secretary. Hitherto, only the Social Democratic and Labour Party and the Alliance Party of Northern Ireland have put their heads over the parapet in supporting tax-varying powers. Currently, council-tax payers in Britain pay some 80 per cent more than ratepayers in Northern Ireland - and they have to fork out for water/sewerage charges too. This very fact undermines regional claims for extra cash from the Treasury: Northern Ireland could enjoy £116 million more expenditure per year if it raised the regional rate to the same proportion of average household income as in England. ${ }^{64}$ But replacing the regional rate by additional income tax in Northern Ireland, among other measures, could remove this deficit in a much fairer way. The Scotland Act gave the Scottish Parliament a power - hitherto unused, but likely to be needed eventually, given the major spending commitments entered into by the parliament - to vary income tax by up to $3 p$ in the pound. A more egalitarian arrangement would be a general power to vary income tax. Thus, for example, it would make more sense in Northern Ireland to restore an upper band of 50 or even 60 per cent (it was 83 per cent only a generation ago, let's not forget) before

63 Op cit at $\mathrm{p} 195$.

64 See further Department of Finance and Personnel, A Review of Rating Policy: A Consultation Paper, (2002) Belfast: DFP. 
raising the basic rate. ${ }^{65}$ This would also be administratively simpler. An increase UK-wide in the top income-tax rate to 50 per cent for those earning over $£ 100,000$ per annum would raise an additional $£ 3.1$ billion a year. On a pro rata basis, this would raise $£ 86$ million a year in Northern Ireland. Given the region has fewer very high earners, however, the actual figure would be significantly lower.

The rating review ${ }^{66}$ recommends a reformed property-based system. But any such system, as the review recognises, then needs to introduce a raft of adjustments to minimise anomalies - for instance, where an elderly single person is living on low income in a large property. Far better to have a simple, efficient and above all fair system that need not duplicate the existing arrangement for income-tax collection. It is, however, right to sustain a property-based system for specifically non-domestic taxation, with reliefs where appropriate. The review suggests this should move from occupation to ownership, as a disincentive to dereliction, collecting some of the $£ 43$ million a year foregone as a result. More seriously, it points out that the blanket de-rating of industrial premises, foregoing $£ 64.3$ million a year, is unique in the world and has a large "deadweight" effect: there has been no demonstrable gain in inward investment. Other, selective, easements could be considered if this were removed, as the review strongly implies it should be. Moreover, agricultural land and buildings are de-rated too, with a potential lost revenue of $£ 215$ million. An exemption would however be required for owners with an income below a reasonable threshold, which given the poor state of farm incomes in recent years would eliminate most of this figure. But a replacement of the regional rate by an income-based alternative could provide the data required to focus such a property tax on major landowners.

While a decision on revenue-raising for local government in Northern Ireland awaits the wider review of sub-regional public administration, again collection of income data within the region could provide the basis for a move to local income tax, replacing the district rate for domestic ratepayers. This would again be more progressive than current arrangements. Remarkably, almost all the debate about redistribution in Northern Ireland has focused on expenditure - a product of a mindset where only the latter is subject to regulation - via "targeting social need". This has required complex administrative exercises and tied up large amounts of resources in the public sector. It goes without saying that in "normal" societies the focus of redistributive effort is primarily on the revenue side, where it is more effectively and efficiently directed. The above measures would have a significant, direct (and measurable) effect on the income distribution in Northern Ireland - none of which applies to TSN.

\section{Water}

Water provides a particular challenge. Currently, the cost of the water service comes out of general public expenditure, without being supported by the rates or by charges as almost everywhere else in the world. The case for

\footnotetext{
${ }^{65}$ See further Civic Forum, A Regional Strategy for Social Inclusion, (2002) Belfast: Civic Forum at $\mathrm{p} 85$.

66 Op cit.
} 
charges and metering, as an incentive for conservation, is a strong one. No one, for example, would suggest that electricity should be free if we were starting from a tabula rasa - though, interestingly, a "consumer service corporation" has been proposed in this arena, as an alternative to the shareholder-led Northern Ireland Electricity, with a view to reducing bills. ${ }^{67}$ The Executive Committee has decided, however, that it will not go down the metering road, because of the capital costs involved. This is worthy of a more open debate.

The Department of Finance and Personnel calculates that investment totalling $£ 3$ billion is needed over two decades to meet EU directives, respond to increasing demand and replace ageing infrastructure, ${ }^{68}$ though it subsequently translates this into only a $£ 50$ million additional funding requirement per annum. ${ }^{69}$ Distributed among some 620,000 households, the annual charges required to fund such investment without resort to borrowing would not be high, even for those on low incomes (some $£ 80$ per year on average, plus administration costs). Were charges to extend to cover the introduction of metering and/or to contribute towards operating costs, of course, charges would have to be higher.

Given the legitimacy issues around charging in Northern Ireland (think of TV licences in west Belfast), a vehicle would need to be established (such as a not-for-profit) that would realise the revenue with minimum hassle. Such a vehicle could also borrow or the proposed Strategic Investment Body could borrow on its behalf (either way, it would be the executive's borrowing power that was the backstop guarantee). Bonds issued would, on the Glas Cymru model, incur cheaper interest than a private alternative. But, reiterating the funding/finance distinction once more, the latter would not be an alternative to charging.

Whether one did or did not decide to introduce water charges should be based on decisions as to how much additional overall expenditure, if any, the executive felt it needed to fund per annum and through what combination of additional taxation and charges it intended to bring it about. Borrowing whether via a private partner or a not-for-profit in the "public" sphere principally affects the phasing of the expenditure, not the total revenue that has, one way or another, to be raised to fund it. Thus, one might want to "float off" the water service to a not-for-profit or social enterprise at arm's length from government for public-policy reasons - that it was more transparent and subject to stricter disciplines, that government should not be involved in such operational activity, and so on. Such an organisation could engage wider stakeholders, operate accountably to a high standard of performance and generate a wider sense of "social ownership" over water. And one could simultaneously be opposed to charges on the grounds that they are inherently inegalitarian, though again there could be exemptions for those on means-tested benefits were charges to be introduced.

Turning to transport, the transport company Translink has the advantages of arm's-length operation and integration across modes, yet its potential is not

67 See further Irish Times June $13^{\text {th }} 2002$.

68 DFP, A Review of Rating Policy op cit n 64 at $\mathrm{p} 41$.

69 DFP, A Review of Public Procurement op cit $\mathrm{n} 58$ at $\mathrm{p} 42$. 
being realised. If a modern public-transport system is to be developed, public subsidy will have to be progressively raised. There is scope for saving by less expenditure on roads, where the latter only achieves a shortterm reduction in congestion to no long-term benefit. But congestion charges are the only obvious way to tackle this problem and generate income to subsidise public transport. Catching suburban travellers into Belfast, such charges would tend to bear hardest on middle-class commuters and would have positive environmental effects. There should be clear hypothecation to public-transport improvement.

\section{Expenditure}

Turning to the expenditure side, there should be no presumption in favour of public- or private-sector projects for service delivery - though there can be a preference for "social" projects where it can be demonstrated that positive "externalities" arise. Every PPP project assessment should be on a case-bycase basis, including a public-sector comparator, and made on broad valuefor-money terms rather than merely accepting the lowest bid. Any talk of promoting a "deal flow", jeopardising VFM accounting, should be abandoned.

Relevant expertise should be concentrated in the heart of government, to minimise the danger of poor contract arrangements being entered into and to ensure a continuous process of lesson-learning (including from elsewhere), reflected in regularly updated dissemination of good practice. Any new unit in the Department of Finance and Personnel should nevertheless liaise closely with the Economic Policy Unit in the OFMDFM, to ensure the full policy-delivery potential of PPPs is realised and that narrowly financial considerations do not constrain it. The devolved administration should also direct greater attention to expenditure reductions. The corollary of saying that it is difficult to defend a 42 per cent spending differential over England is that there are inefficiencies in how money is spent in Northern Ireland.

Sectarianism and social division are obvious sources of inefficiency. Education in Northern Ireland costs 44 per cent more per head than in England. ${ }^{70}$ This is partly to do with a more dispersed system. But the insistence of vested religious and class interests in maintaining fragmented schooling arrangements - which the recent Burns review would not fundamentally affect - comes at a heavy price in the poor quality of the school estate. It is perfectly legitimate for the guardians of the public purse elected politicians - to indicate that they have a policy preference for shared rather than segregated policy provision, in this and other areas. For example, currently, when a new greenfield housing development is completed, the default option is to build a "controlled" (state but de facto Protestant) school there and await a request from the Catholic authorities that a "maintained" school be added. The default option should be an integrated school, on grounds of financial probity as much as to discourage the socialisation into enemy images that a segregated system is widely recognised as fostering.

Were the executive to adopt this broad policy approach, it would maximise devolved fiscal autonomy on the one hand and, on the other, allow genuine

70 HM Treasury (2002), loc cit. 
innovation in service delivery through a plurality of arrangements while allowing the administration to concentrate on core, strategic functions. It would thus make it easier both to "sell" the need for revenue-raising and to avoid confrontations with unions or "anti-privatisation" campaigns.

\section{Accountability}

Turning to accountability, the complexity of PPPs and the associated confusion, allied to Northern Ireland's endemic culture of mistrust, mean that the rules of the game must be clearly set, they must be clearly understood and they must be clearly fair. The engagement of the social partners via the OFMDFM Working Group on PPPs should be sustained, particularly given the continuing reservations of the trade unions.

In the Republic of Ireland, a framework document on PPPs was only agreed after it had gone through 21 drafts via the PPPs advisory group there. The Public-Private Advisory Group Paper on PPPs says that the development of PPPs should take place "within the overall process and structures of social partnership". ${ }^{71}$ The OFMDFM Working Group Paper ${ }^{72}$ also commends a social-partnership approach, though the Working Group would need to be rebalanced towards the trade unions and voluntary sector if it were to provide the nucleus for continuing engagement, including in monitoring, evaluation and review.

Such an approach is endorsed in the Executive Committee's initial response to the working-group report, ${ }^{73}$ but there is no tangible commitment beyond compliance with "legislative requirements". But it will be impossible to sustain social partnership over PPP contracts unless there is a willingness to go at least as far as the republic has done in endorsing the application of industry-wide norms and agreements. The UK government's new code requiring new employees to receive "comparable" wages and conditions to those of transferees is more than legislation requires but falls short of endorsing a negotiating role for trade unions. ${ }^{74}$

The relevant trade unions should also be given access to the outline business case for a particular project at the earliest stage. The assumptions behind value-for-money comparisons with a PSC are often contestable and these should be subject to genuine debate. Unions should also be able to suggest potential bidders and talk to those shortlisted about employment issues. Over and above legal requirements, the devolved administration should follow the Treasury Taskforce guidelines in these regards, ensuring workforce representatives are engaged at every stage.

\section{Role of ministers}

It should be made clear that policy on PPPs is evidence-based rather than ideology-based. The full range of potential partners - such as voluntarysector organisations - should be considered in each case. Recognising the diversity of models, pilot projects and rigorous evaluation should be the

11 Public-Private Advisory Group on PPPs op cit $\mathrm{n} 39$.

72 Op cit at $\mathrm{p} 156$.

73 Northern Ireland Executive, op cit $\mathrm{n} 12$.

74 Guardian, March 27 2002. 
order of the day. Ministers need to make clear in public speeches that PPPs are not privatisation-by-stealth, they are not reducible to PFI and the latter is not "the only show in town". They should highlight their positive potential for service delivery with NGO partners and stress the importance of valuefor-money considerations, workforce safeguards and public accountability.

Many of these issues could be addressed, and publicly debated, via the introduction of legislation, as in the republic, setting the framework for PPPs in a regulatory rather than constraining fashion. The potential for mutual lesson-learning across the island should be vigorously pursued, via relations between PPP units north and south.

The Economic Policy Unit in OFMDFM should ensure that in future iterations of the Programme for Government the discussion of PPPs is not "crowded out" by the funding argument and so by PFI. The "Working Together" chapter should be reconceived in a much broader way as a chapter on governance in the round. The third paradigm outlined above should be the inspiration for innovation. This would also help avoid the danger inherent in the PfG process of a routinisation of the annual iteration and a loss of wider public interest.

Ministers also need to show genuine collective responsibility in educating the Northern Ireland public about the "hard choices" of devolved government, when revenue is finite and demand apparently infinite. They must resist the temptation to engage in populist competition which blocks necessary revenue-raising or unrealistically inflates expenditure expectations. And they must, above all, make plain that there is no such thing as a publicexpenditure "free lunch".

The blunt reality remains that if the citizens of Northern Ireland want European-level public services they must be willing - with the burden distributed equitably - to pay for them. That will mean paying more - not less, as currently - than the UK average and can only be achieved if the region has tax-varying powers. There may well not be the requisite willingness to embrace additional taxation for those who can afford it. But it would be an interesting test of those parties who profess egalitarian commitments as to whether they recommend such change. Stimulating a genuine left-right divide in politics in Northern Ireland would, in itself, be highly beneficial to its democratic health.

\section{CONCLUSIONS}

Public-private partnerships represent a challenge for the devolved administration perhaps typical of those it will face if it survives into the future. The issues are complex and it is very difficult to get a handle on this complexity in the absence of a left-right policy divide. There has been a huge debate about PPPs in Britain, but as ever distracted by other concerns little of this has been reflected in the public domain in Northern Ireland even though Treasury assumptions about devolution were that PPPs would play a greater role in Scotland, Wales and Northern Ireland than in the UK as a whole. And the issues are tied up - or mixed up - with the hard choices the region faces in the context of finite budgetary self-management.

As a result, there is much confusion about PPPs, which risks failure to avoid their pitfalls while not capitalising on their potential. In particular, there is a 
widespread tendency to assume that they are reducible to the Private Finance Initiative - whereby major capital projects are financed by the private sector - and that PFI offers something for nothing in a context of publicexpenditure restraint. In fact, however projects are financed, in the absence of user charges they remain funded by the public purse. A naïve embrace of PFI would risk locking the public sector in Northern Ireland into long-term financial commitments offering poor value for money for the taxpayer.

It is right for government, at all levels, to look around for potential partners for the delivery of projects and services: society these days is too complicated even for a regional administration to be all-knowing and alldoing. Creating an environment of contestability keeps the public sector on its toes and a well-drawn contract with a private provider can offer efficiencies because the partner has a stake in securing them. But the transaction costs of public tendering can be high and private partners seek a profits stream. And because companies, unlike governments, can go bankrupt they pay higher interest on capital they in turn borrow to finance PFI projects. So value for money is by no means assured and has to be assessed, against a public-sector comparator, on a case-by-case basis. There should be no ideologically-driven preference for the private sector. In particular, there should be no a priori commitment to PFI because of the fiscal constraints on the devolved administration. This would be to fall for the something-for-nothing fallacy. Now that the Chancellor has granted Northern Ireland, unlike Scotland and Wales, borrowing powers on its own account, there should be no suggestion that PFI is "the only show in town".

Guarantees are also needed that there will be a level playing-pitch. In the UK, a big factor in the debate about PFI has been trade-union fears of a "two-tier workforce", where contractors would employ new workers at poorer terms and conditions than those transferred from the public sector. PPPs have proved significantly less contentious in the republic, partly because of the absence of an effective left-right divide there too, but also because there has been a willingness to accept that industry norms and agreements should apply to all in the context of social partnership. This approach should be endorsed by the devolved administration, which should also maximise the exchange of experience via north-south structures.

A broader view of PPPs is however also needed. Any savings secured by value-for-money PFI projects will be marginal to the funding requirements of the devolved administration. There needs to be a willingness to consider new sources of revenue since all borrowing - public or private - has to be paid for in the end, and with interest. European-level public services cannot be delivered without European-level taxation.

In particular, the devolved administration needs to grasp the nettle of seeking regional income-tax varying powers, which would in any event be a fairer way to raise money from domestic payers than the rates. The rates review should be used as an opportunity to remove loopholes for manufacturing and, above an income threshold, agricultural property-owners, while the district rate should be replaced by a local income tax. And, where appropriate, charges need also to be considered - for water and to reduce congestion albeit with exemptions for those on subsistence benefits. 
The most innovative and exciting partnerships, moreover, are those involving policy delivery, where the partner - who may well be drawn from the voluntary sector - can bring specialist expertise or user engagement or may otherwise add "value" to what government does. Ministers are anxious that they make a devolved "difference". A major way to do so would be to open up Northern Ireland's fairly conservative governance arrangements to the fresh winds of wider engagements. In particular, a not-for-profit solution should be explored to the challenge of renewing the water system. This has been successfully tried in Wales and could not only introduce efficiencies into the system but also provide the only way in which the introduction of charges could be legitimised. 